\title{
Student Attitudes toward Instructional Technology in the Large Introductory U.S. Government Course
}

\author{
Kenneth R. Mayer, University of Wisconsin, Madison \\ John J. Coleman, University of Wisconsin, Madison
}

\begin{abstract}
Instructional technology-computer-based lectures, email, World Wide Web resources, multimedia, the Internet-has become a pervasive part of the political science classroom (Crawford 1998; Garson 1998; Kiasatpour 1999; Kuzma 1998; Jerome Young 1998). Computer simulations and other instructional technologies have been around for more than a decade, and more and more faculty in all areas of academia are moving to computerbased instruction. The Campus Computing Project (1998), which conducts an annual survey of computer use in higher education, estimated that in 1998 nearly $45 \%$ of college and university courses used email (a 400\% increase since 1994), one-third of all courses used Internet resources (up 100\% since 1996), and nearly one-quarter used web pages for course materials (up 350\% since 1994).
\end{abstract}

\footnotetext{
Kenneth R. Mayer's teaching and research interests are in American government and institutions, defense policy, and campaign finance. He was named a Lilly Teaching Fellow for the 1993-94 academic year. He is the author of The Political Economy of Defense Contracting (Yale University Press, 1991) and is currently writing With the Stroke of a Pen: Executive Orders and the Presidency, forthcoming from Princeton University Press, which investigates how presidents have used Executive Orders to implement major policy initiatives.

John J. Coleman's teaching and research interests are in the evolution of the American state and the relationship between changes in the political economy of the United States and its party structure. He is the author of Party Decline in America: Policy, Politics, and the Fiscal State (Princeton University Press, 1996) and articles on party organizations, elections, Congress, and international trade. His current research includes projects on bipartisanship and campaign spending.
}

Despite considerable enthusiasm among many academics for computer-assisted instruction and a widespread belief that use of new technologies will produce a revolution in teaching and learning (McArthur and Lewis 1998), some observers urge caution and skepticism (see, e.g., Neal 1998). Privateer, for example, has argued that it is a mistake to assume that use of technology, by itself, "produces new ways of learning" (1999, 67). Indeed, in his view, educators have not made effective use of technological resources. "It is clear that the majority of contemporary uses of instructional technology still reflect eighteenth-and nineteenth-century notions of teaching and instructional delivery" (77). Technology can be nothing more than "bells and whistles" that lead instructors to substitute fancy graphics and glitzy presentations for substantive teaching strategies and coherent thought. Making the transition from a traditional "chalk and talk" course to a computerbased one can be enormously time consuming and expensive, leading to concerns (especially among untenured faculty) about whether the investment in "computerizing" their teaching is worth the price (Guernsey 1999). More broadly, many members of the academy express the fear that the use of instructional technology will be judged primarily on how it affects faculty productivity, not instructional quality, and that financial pressures will force universities and colleges to replace professors with computers-through distance education, video conferencing, online laboratories, and the like (see Jeffrey Young 1998b). ${ }^{1}$

Part of the problem is that efforts to integrate technology into the classroom have not been matched by commensurate efforts to assess the effectiveness of the new techniques. As Gizzi and Wilkerson have argued persuasively, "the pace of the instructional technology revolution has moved faster than our ability to react to it and assess its utility as a tool to enhance student learning in the classroom" $(1998,1)$. What little data have been collected from controlled evaluations suggest that multimedia technologies, computerized instruction, and distance education techniques have, at best, only minimal effects on student performance (Janda 1992; Jordan and Sanchez 1994; Wilson 1996), and the precise impact may never be determined because there is no feasible way to conduct experiments that can fully isolate the influence of technology. ${ }^{2}$ The only consensus among those who have studied the effectiveness of informational technology is the somewhat obvious point that it is not the technology that matters, but what teachers do with it (Bollentin 1998).

Stephen Ehrman (1995, 1998, 1999) has suggested that researchers would do best to look beyond outcomes and ask whether technology can help instructors integrate "best practices" into their teaching. ${ }^{3} \mathrm{We}$ agree. Educators have very little systematic data about even the most basic questions: What do students think about the technology? How do they assess the effectiveness of technology as an aid to learning? How do their behaviors and assessments depend on different instructors and teaching strategies? Does the use of technology affect the content, presentation, and organization of lectures and other course materials? How does it help-or hinder-a teacher's ability to provide effective instruction? Answering these ques- 
tions is especially important for teachers of larger lecture courses, who face uniquely difficult pedagogical challenges.

Over a two-year period, we collected data that can help us answer some of these questions. Beginning in the fall of 1997, we revised our introductory American government courses to incorporate various instructional technologies. Specifically, we integrated video clips and graphics (charts, graphs, pictures, data tables, drawings, diagrams) into lectures, made course materials available on the web, required students to find resources on the web for doing activities and assignments, and presented lectures with presentation software. ${ }^{4}$ We taught the courses in a recently remodeled multimedia classroom. The lecture hall, which could seat 418 , did not even have a chalkboard, although a small "whiteboard" was installed at faculty's insistence. We have each taught three large sections of this course, once each in 1997,1998 , and 1999 , to more than 2000 students. At the end of each section, we distributed a short, 10-item survey with the final exam that asked students about their attitudes toward the technologies used in the course. 5 Standard course evaluations used by the political science department had been administered about three weeks earlier.

We now have a large database of student attitudes toward technology in the classroom. Although we did not teach any of these courses as "controls," we differed on enough aspects of course administration and teaching, and have a large enough population, that we can identify, broadly, whether the different strategies we employed altered students' attitudes and behavior. Below, we offer our own anecdotal impressions of the costs and benefits of adopting computer technologies, as well as an analysis of the student survey data.

\section{The Payoffs (and Pitfalls?) of Instructional Technology}

Each of us was comfortable using computer technology and found that we adapted relatively quickly to the demands of multimedia lecturing. We each presented all our lectures in this format and made the content of our slides available on our course web sites. We also put charts and graphs shown in class onto the web sites, and used email extensively to answer student questions and provide information to the entire class. Coleman assigned some class and discussion section activities that required students to use the web. Neither of us had any explicit attendance policy at lecture, although attendance at discussion sections did figure into students' course grades.

Integrating new technology into instruction alters course dynamics for faculty as well as for students. Accordingly, we consider both our and our students' experiences in these six sections of the introductory U.S. government course.

\section{The Faculty Perspective}

We quickly found that converting lectures to slide format had two advantages and two disadvantages. The first advantage was that we were forced to improve the flow and clarity of our lectures. Like most instructors, we did not worry much about how our notes looked since no one would see them. Translating the notes into the outline format of presentation software required us to carefully map what we wanted to say and how we planned to say it. Consequently, the content of the slides was more organized than the notes we had used previously. When preparing the slides, we finally incorporated those notes scribbled in the margins, made deletions, rearranged the list items, added new examples, and so on, creating a coherent presentation that had to stand on its own. In transferring this content to slides, we discovered flaws that inevitably creep into lectures-incomplete material, poorly expressed thoughts, points presented in less than optimal order. One reason these flaws emerge when converting

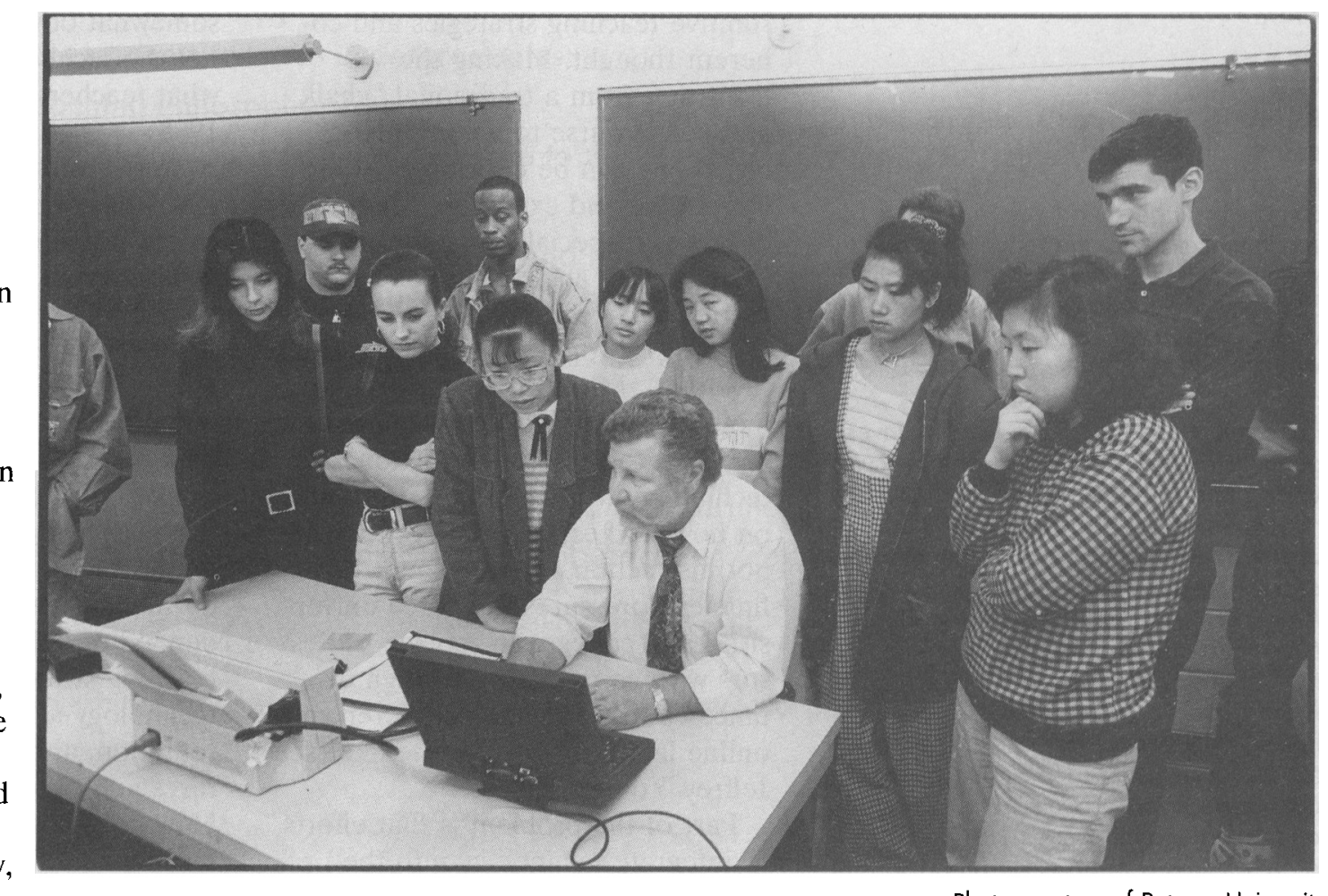




\begin{tabular}{|c|c|c|c|c|c|c|c|}
\hline \multirow[b]{2}{*}{$\begin{array}{l}\text { 1. Technology-enhanced } \\
\text { lectures compared to } \\
\text { traditional lectures }\end{array}$} & \multicolumn{2}{|c|}{1997} & \multicolumn{2}{|c|}{1998} & \multicolumn{2}{|c|}{1999} & \multirow[b]{2}{*}{ Total } \\
\hline & Coleman & Mayer & Coleman & Mayer & Coleman & Mayer & \\
\hline $\begin{array}{l}\text { Much more interesting } \\
\text { More interesting } \\
\text { Not much different } \\
\text { Less interesting } \\
\text { Much less interesting }\end{array}$ & $\begin{array}{l}60.4 \% \\
33.5 \\
5.9 \\
.3 \\
.0\end{array}$ & $\begin{array}{l}60.6 \% \\
33.9 \\
3.9 \\
1.4 \\
.2\end{array}$ & $\begin{array}{l}50.0 \% \\
43.3 \\
6.0 \\
.7 \\
.3\end{array}$ & $\begin{array}{c}63.1 \% \\
32.1 \\
3.7 \\
.6 \\
.6\end{array}$ & $\begin{array}{l}71.0 \% \\
25.6 \\
2.7 \\
.0 \\
.7\end{array}$ & $\begin{array}{l}59.0 \% \\
37.5 \\
2.8 \\
.4 \\
.4\end{array}$ & $\begin{array}{l}60.7 \% \\
34.2 \\
4.2 \\
.6 \\
.3\end{array}$ \\
\hline \multicolumn{8}{|l|}{$\begin{array}{l}\text { 2. Ease of taking notes } \\
\text { compared to traditional } \\
\text { lectures }\end{array}$} \\
\hline $\begin{array}{l}\text { Much easier } \\
\text { Easier } \\
\text { Not much different } \\
\text { Harder } \\
\text { Much harder }\end{array}$ & $\begin{array}{r}72.6 \\
22.0 \\
3.3 \\
2.1 \\
.0\end{array}$ & $\begin{array}{r}72.1 \\
20.4 \\
4.8 \\
2.4 \\
.2\end{array}$ & $\begin{array}{r}74.1 \\
20.1 \\
2.7 \\
2.4 \\
.7\end{array}$ & $\begin{array}{r}80.1 \\
15.1 \\
1.4 \\
2.8 \\
.6\end{array}$ & $\begin{array}{r}80.8 \\
13.8 \\
3.0 \\
2.0 \\
.3\end{array}$ & $\begin{array}{r}80.4 \\
15.1 \\
2.5 \\
2.1 \\
.0\end{array}$ & $\begin{array}{r}76.3 \\
18.1 \\
3.0 \\
2.3 \\
.3\end{array}$ \\
\hline \multicolumn{8}{|l|}{$\begin{array}{l}\text { 3. Effect of lecture slides } \\
\text { on pace of class }\end{array}$} \\
\hline $\begin{array}{l}\text { Too quick } \\
\text { Just about right } \\
\text { Too slow } \\
\text { Did not seem to affect }\end{array}$ & $\begin{array}{r}11.9 \\
73.5 \\
1.6 \\
13.1\end{array}$ & $\begin{array}{r}18.0 \\
68.0 \\
2.2 \\
11.9\end{array}$ & $\begin{array}{r}16.0 \\
68.0 \\
2.1 \\
13.9\end{array}$ & $\begin{array}{r}21.4 \\
67.4 \\
1.4 \\
9.7\end{array}$ & $\begin{array}{r}16.8 \\
71.0 \\
1.0 \\
11.1\end{array}$ & $\begin{array}{r}13.0 \\
72.6 \\
1.4 \\
13.0\end{array}$ & $\begin{array}{r}16.3 \\
70.0 \\
1.6 \\
12.1\end{array}$ \\
\hline \multicolumn{8}{|l|}{$\begin{array}{l}\text { 4. Effect of technology- } \\
\text { enhanced lectures on } \\
\text { learning course material }\end{array}$} \\
\hline $\begin{array}{l}\text { Much more effective } \\
\text { More effective } \\
\text { Not much different } \\
\text { Less effective } \\
\text { Much less effective }\end{array}$ & $\begin{array}{r}58.6 \\
35.8 \\
5.1 \\
.5 \\
.0\end{array}$ & $\begin{array}{r}53.0 \\
39.3 \\
5.5 \\
1.9 \\
.2\end{array}$ & $\begin{array}{r}50.3 \\
42.0 \\
6.4 \\
1.0 \\
.3\end{array}$ & $\begin{array}{r}55.7 \\
37.5 \\
4.8 \\
1.4 \\
.6\end{array}$ & $\begin{array}{r}53.9 \\
40.7 \\
4.4 \\
.7 \\
.3\end{array}$ & $\begin{array}{r}49.1 \\
45.3 \\
5.3 \\
.4 \\
.0\end{array}$ & $\begin{array}{r}53.7 \\
39.7 \\
5.3 \\
1.0 \\
.3\end{array}$ \\
\hline
\end{tabular}

lectures to slide format is that traditional lectures traffic in the spoken word, enhanced by the abbreviated notes placed on a chalkboard. Presentation software relies much more on the written, visual word. In the end, we both felt that our lectures were more coherent and organized in the new format than they had been when we delivered them from notes.

The second major advantage of using presentation software was that it became casy to incorporate graphs, charts, movies, and sounds into lecture. We could present graphics without having to fiddle with overhead transparencies or distribute copies to the entire class (a process that could, with enrollments of 350 or more students, take several minutes, disrupt concentration, and eat up our department's photocopy budget). By using digitized video and sounds, we were able to move easily back and forth between text and multimedia, with few delays or missed cues.

The first major disadvantage was that preparing the initial set of presentation slides took a very long time. Instructors should expect to spend two to three hours converting a single lecture's worth of paper notes to slide format. Additional, often substantial, time should be reserved for reorganizing and improving the flow of the lecture. Add- ing new material increases the time commitment further, as does inserting video clips, charts, pictures, graphs, diagrams, data tables, and so on. Most instructors who convert their lecture notes to a multimedia presentation will discover that they spend substantial time finding, developing, and entering new material that they could not use when delivering lectures in a traditional format.

The second problem is perhaps not so much a disadvantage as a challenge. There is a substantial amount of on-the-job learning. Sometimes this is compelled by the technology itself-video clips that work superbly in the office fail in the 


\section{TABLE 2A}

\section{Online Note Availability and Self-Reported Attendance}

"How many times did you skip class primarily because you knew you could get the notes from the web?"

\begin{tabular}{lccc}
\hline & $\begin{array}{c}\text { Section with } \\
\text { Full Note } \\
\text { Availability }\end{array}$ & $\begin{array}{c}\text { Sections with } \\
\text { Selected Note } \\
\text { Availability }\end{array}$ & $\begin{array}{c}\text { Sections with } \\
\text { Limited Note } \\
\text { Availability }\end{array}$ \\
\hline None & $43.3 \%$ & $62.6 \%$ & $78.4 \%$ \\
1 or 2 times & $(179)$ & $(399)$ & $(762)$ \\
3 or more times & $38.7 \%$ & $27.5 \%$ & $16.6 \%$ \\
& $(160)$ & $(175)$ & $(161)$ \\
\hline$\chi^{2}=169.7 ; p<0.001$ & $17.9 \%$ & $9.9 \%$ & $5.0 \%$ \\
& $(74)$ & $(63)$ & $(49)$ \\
\hline
\end{tabular}

classroom; the video projector or cordless microphone takes a coffee break at the most inopportune time; you forget that one little step that makes something work correctly, and invariably remember it right after class. Even tweaking the advanced lighting system in the room to get it "just right" could drive an instructor to distraction. Other lessons-learned-by-doing came from dealing with the students' receipt of this technology. For instance, Coleman found it necessary to emphasize to his students that simply copying a list of bullet points from the slides was not going to help them study for an exam unless they also jotted down some of the examples or extended descriptions and definitions provided in class. Stu- dents need to understand that everything that they "need to know" for the class is not contained on the slides. Mayer found that students usually tried to copy down all of the slide text verbatim, even when a slide contained a long textual passage from one of the readings that was shown for emphasis. We both learned quickly that there are times when students have to be told to put down their pens.

A second instance of on-the-job learning resulted from our initial and independent decisions to make lecture slides available online before the class in which they were presented. We thought that having copies of the slides would allow students to concentrate more on what we said than on what they had to

\section{TABLE 2B}

\section{Online Note Availability and Perception of Other Students' Attendance}

"Students are more likely to miss class when they know they can get the lecture outlines from the web site."

\begin{tabular}{lccc}
\hline & $\begin{array}{c}\text { Section with } \\
\text { Full Note } \\
\text { Availability }\end{array}$ & $\begin{array}{c}\text { Sections with } \\
\text { Selected Note } \\
\text { Availability }\end{array}$ & $\begin{array}{c}\text { Sections with } \\
\text { Limited Note } \\
\text { Availability }\end{array}$ \\
\hline Agree & $59.6 \%$ & $46.9 \%$ & $36.8 \%$ \\
Not sure & $(246)$ & $(299)$ & $(358)$ \\
Disagree & $20.6 \%$ & $25.1 \%$ & $27.1 \%$ \\
& $(85)$ & $(160)$ & $(264)$ \\
\hline$\chi^{2}=66.9 ; p<0.001$ & & $27.9 \%$ & $36.1 \%$ \\
& $(8.9 \%$ & $(178)$ & 352 \\
\hline
\end{tabular}

write down; it can be disconcerting to try to get a point across while all the students are looking at and transcribing words off a big screen. Although we worried that students who saw the slides before class might be frustrated with the pace of the lecture ("Will you please get on with it?!?"), this was not a problem, even though we did have to slow down to accommodate those students who had not viewed or printed the slides before class. On the other hand, the availability of the slides may affect attendance, particularly if the slides are relatively detailed and comprehensive. Mayer found that he had to warn the students in his 1997 class that he would stop making slides available if attendance dropped precipitously. He provided only edited and condensed slides online for his 1998 and 1999 offerings of the course to preempt attendance problems.

\section{The Student Perspective}

Survey data from our six course offerings, which we present in tables 1 through 3 , reveal several consistent findings about the new instructional technology. Here, we offer an analysis of student response to this technology, focusing primarily on the consistency of results across the six offerings of the course. Differences between the sections are highlighted when they are pedagogically significant. Central findings include the following.

\section{Students Like It}

Students overwhelmingly favor the use of computer-based presentations. Across all six sections, $95 \%$ of students said that instructional technology made lectures more interesting or much more interesting (question 1 in Table 1). Ninety-four percent said that the technology made note taking easier or much easier (question 2). Most importantly, $93 \%$ of students felt that the computer-based lectures were more effective or much more effective than traditional techniques in helping them learn the material (question 4). The vast majority of students $(87 \%)$ rated the technology 
TABLE 3

Class Year Effects

\begin{tabular}{|c|c|c|c|}
\hline $\begin{array}{l}\text { Entered as } \\
\text { freshman }\end{array}$ & $\begin{array}{l}\text { Technology made } \\
\text { it "much easier" } \\
\text { to take notes }\end{array}$ & $\begin{array}{l}\text { Technology made } \\
\text { lectures "much } \\
\text { more interesting" }\end{array}$ & $\begin{array}{c}\text { Technology was } \\
\text { "much more effective" } \\
\text { in learning }\end{array}$ \\
\hline 1996 & $\begin{array}{c}67.6 \% \\
(302)\end{array}$ & $\begin{array}{c}56.8 \% \\
(254)\end{array}$ & $\begin{array}{c}52.1 \% \\
(233)\end{array}$ \\
\hline 1997 & $\begin{array}{c}76.0 \% \\
(545)\end{array}$ & $\begin{array}{c}60.7 \% \\
(435)\end{array}$ & $\begin{array}{c}54.8 \% \\
(393)\end{array}$ \\
\hline 1998 & $\begin{array}{c}81.6 \% \\
(421)\end{array}$ & $\begin{array}{c}61.8 \% \\
(319)\end{array}$ & $\begin{array}{c}56.0 \% \\
(289)\end{array}$ \\
\hline 1999 & $\begin{array}{c}82.7 \% \\
(196)\end{array}$ & $\begin{array}{c}69.6 \% \\
(165)\end{array}$ & $\begin{array}{c}52.7 \% \\
(125)\end{array}$ \\
\hline 2-way $x^{2}$ & $40.3(p<.001)$ & $21.4(p<.05)$ & 14.8 \\
\hline
\end{tabular}

positively on all three of these questions.

Student interest in lectures correlates with a belief that instructional technology enhances learning $(\mathrm{r}=$ $.53, p<.001)$ and with the view that technology helps with note taking $(\mathrm{r}=.38, p<.001)$. While we lack definitive evidence about the direction of these relationships, we think it reasonable to conclude that increased interest leads to enhanced learning, rather than the other way around, and that the ability to take notes and follow lectures more easily contributes to a sense that the lectures are more interesting when delivered via instructional technology. In any case, we believe strongly that our use of instructional technology helped students engage with the material, whether student interest precedes more attentiveness or vice versa. Students do not learn when they are bored silly. If they feel lost, they quickly lose interest. And whether students are bored or lose interest can depend heavily on the pace of a lecture, whether traditional or computer-enhanced. Students found the pace of the computer-enhanced lectures comfortable. About $70 \%$ felt that the lecture pace was about right, $16 \%$ thought the pace was too quick, and only $2 \%$ complained that the lecture pace was too slow (question 3 in Table 1).

\section{Slide Detail Affects Web Use} differed was the availability of detailed notes on the course web pages. In one of the course sections, students had access to the detailed, comprehensive slides presented in class. In two other sections, students could view and print only summary slides that included higher-level bullet point information but not subpoints. Students in the three remaining sections had access to slides as presented in class, but these slides tended to be less detailed and comprehensive than those in the first type. For our analysis, we designated the first type a "full note availability" section, the second a "selected note availability" section, and the last a "limited note availability" section.

Students offered varying opinions about how useful these online slides were in helping them learn the material, with much of the variation depending (not surprisingly) on whether they had access to full notes. Fifty percent of the students in the full note section found that the online sides helped them "very much" in learning the course material; only $16 \%$ said that the online slides made little difference. Students enrolled in lectures with less complete note availability were much less likely to think that the online slides were useful. Only $24 \%$ in the limited note availability sec-
One area in which the six courses tions rated the online notes as very helpful in learning the material, and $37 \%$ felt that they made little difference. Comparable figures for students in the selected note sections were $40 \%$ and $28 \%{ }^{6}$

Our survey data show that students did take advantage of the online lecture material. Again, students in the section with full online notes were much more likely to view and print slides $(73 \%)$ than were those in sections with limited notes $(43 \%)$. While in one sense these results are obvious-less comprehensive notes provide less of an incentive to go to the web and download the slidesthey do indicate that students were willing to think about or review lecture notes outside of class. The most popular method of using the detailed notes (apart from skipping class-see below) was to download them before classes and use the printed copies as templates for taking additional notes during lectures.

\section{Slide Detail and Online Strategy Affects Attendance}

In teaching about American government, each of us stresses the difficulties of reconciling competing goals and interests (e.g., equality and efficiency, responsiveness and responsibility, majority rule and protecting minority rights). And so it is with instructional technology. Although students feel that having access to complete lecture notes online is a useful learning tool, that utility comes at a price-from our perspective, at least. If students feel they can learn outside of class, they may not show up for class in the first place. As Table 2A shows, placing detailed notes on the course web page dramatically increased the likelihood that students would consider skipping class and relying exclusively on the contents of the slides. Well over half of the students in the full note availability section, which met twice each week, admitted missing at least one lecture because they knew they could still obtain the material online, and nearly one-fifth admitted to missing at least 3 times for this reason. In contrast, about $37 \%$ of students in the selected note availability sections missed class because of the availability of web notes. Stu- 


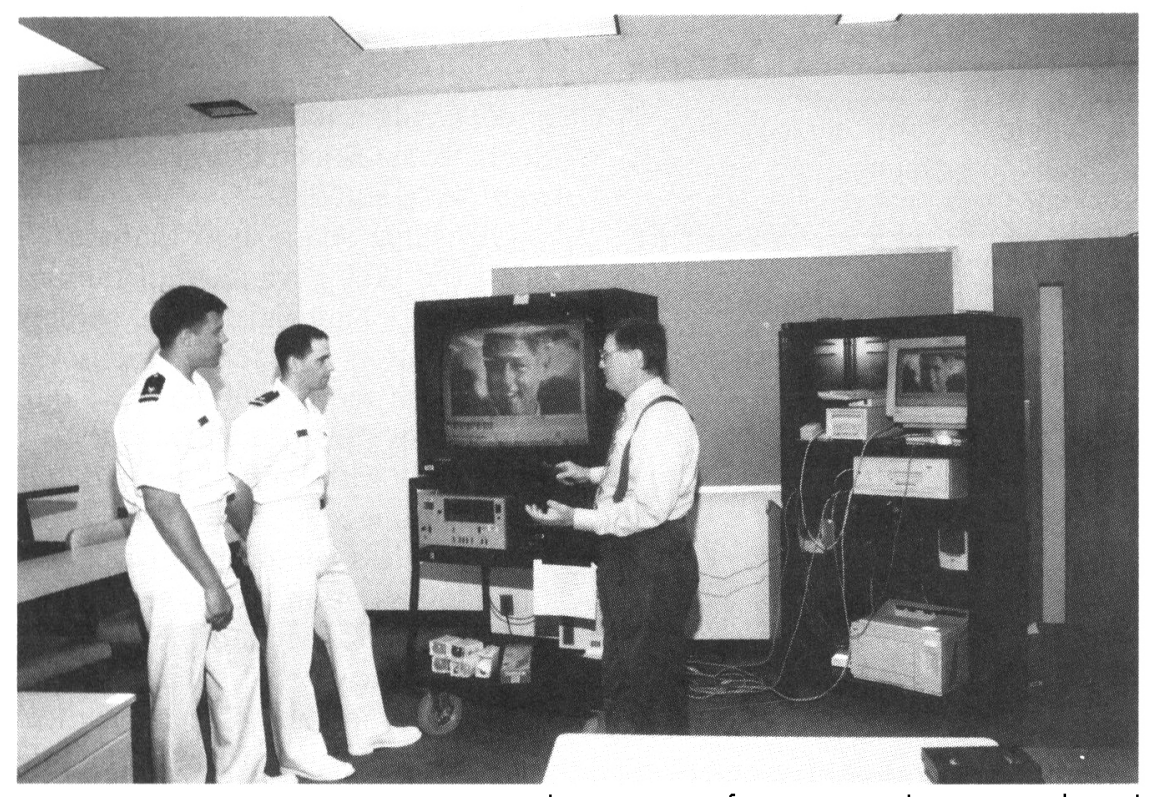

Photo courtesy of Steve Frantzich, U.S. Naval Academy.

dents in the limited note availability sections were more faithful attendees yet: Only a little more than onefifth of these students missed class because they could get notes from the web.

Remarkably, $60 \%$ of students in the full note section also believed that other students were more likely to miss class if they knew they could get the slides off the web. Only $37 \%$ in the limited note sections believed this (Table 2B). These numbers are consistent with our informal observations of class attendance. While we weren't surprised to see some effect, we were struck by the magnitude and consistency of the difference. Currently, neither of us offers full note availability.

We found that students who skipped class themselves were far more likely to think that other students would skip. Among students who reported never skipping class because of web notes, $37 \%$ agreed that, in general, students are more likely to miss class when they know they can get the lecture notes online. Among students who reported missing 3 or more times, $83 \%$ agreed. The significance of this relationship holds for all of the course sections, and is not due to the unusually high rate of self-reported absences among students in the full note lecture. While this finding may appear to be obvious - though we note that previous reports of depressed attendance due to web use have been largely anecdotal (Schwartz 1997) -it highlights some connections between the "culture" of a class and individual behavior that teachers should keep in mind. Martocchio (1994) found a clear connection between what he called an "absence culture" and individuallevel absences in work settings, noting that when individuals begin to see absences as legitimate and normal, their own attendance is likely to suffer. Researchers have found the same relationship to hold for cheating among students, with higher misconduct rates associated with a perception that "peers cheat and are not penalized" (McCabe, Trevino, and Butterfeld 1999, 211). There is little doubt that in the full note section, some students became acculturated to the idea of missing class at least every now and then.

Obviously, providing detailed online slides has tradeoffs. Doing so gives students more useful material to review outside class, but also gives them an incentive to miss class. Class attendance matters because in-class presentation of the material expands upon and elaborates the material presented on the slides. Instructors will have to weigh these advantages and disadvantages for themselves. ${ }^{7}$ Of course, instructors in small classes-where individ- ual absences are noticeable, and where specific attendance policies can eliminate the temptation to skip-will not face the same sorts of problems we did.

\section{A Building Wave?}

We detected a "generational effect" in which younger students were more likely to have a positive view of instructional technology than were older students. Freshmen taking the class were generally more enthusiastic about the course technology than were sophomores. For example, $66 \%$ of the freshmen felt that our use the technology made lectures much more interesting, compared to $58 \%$ of the sophomores $\left(\chi^{2}=19.4, p<.001\right)$. About $73 \%$ of sophomores reported that the technology made note taking much easier; $81 \%$ of freshmen took that position $\left(\chi^{2}=23.1, p<.001\right)$. And freshmen were more likely to think that the technology helped them learn the course material more effectively than sophomores $(58 \%$ to $\left.52 \% ; \chi^{2}=12.5, p<.01\right)$. Our limited survey instruments do not permit us to examine these results in more detail, but we think it is plausible to suggest that first-year students are likely to be less confident in their note taking and study skills than are more advanced students, and therefore rely more on the slides to give some structure and organization to their classroom experiences. Since advanced web browsers are only a few years old, a second possibility is that new students are more familiar with webbased materials, especially if they own their own computer. We do know that freshmen were more likely than sophomores to use their own computer to access course materials (61\% compared to $54 \%$ ), and less likely to rely on campus computer labs for this purpose $(20 \%$ to $24 \%$ ).

Another way to examine whether there is a building wave of students willing and able to use instructional technologies is to classify students by the year in which they entered college as freshmen. Table 3 shows that recently matriculated students are more likely to express support for instructional technology as a part of 
the classroom experience than their predecessors. Belief that technology made it much easier to take notes in class is 15 points higher among students that entered in 1999 than among students who entered in 1996. Belief that technology made lectures much more interesting is 13 points higher. On the other hand, there is no generational difference in students' assessments of the effectiveness of technology in helping them learn course material. As we noted above, this general support for instructional technology among younger students may reflect greater familiarity with these technologies in other contexts. Seventy percent of 1999 freshmen indicated that they accessed class lecture notes by using their own computers, but only about $45 \%$ of 1996 freshmen accessed notes that way. We find this encouraging, for it suggests that recently enrolled students do not evince a "been there, done that" attitude toward the technology that diminishes their support. To test for saturation effects, we asked students in our 1999 survey whether they had taken other courses that relied on the instructional technology we used in our classes. We found virtually no difference in support for the technology between those who had not taken such a course previously, those who had taken a course in which the technology was used sparingly, and those who took a course in which the technology was used in at least half the classes. The view that technology was much more effective in helping the student learn the material ranges from 52 to $53 \%$ across these three groups. Belief that the technology made the course much more interesting ranges from 64 to $66 \%$. And 80 to $83 \%$ of the students thought the technology made note taking much easier. Familiarity, it would seem, does not breed contempt. ${ }^{8}$

\section{Much Ado About Something?}

Our survey results show clearly that students like this technology and find that it makes class more interesting, note taking simpler, and learning course material easier. Students also told us that they appreciated being able to listen to lectures without worrying whether they had written down every important word; if they missed something, they could check the slides on the web. Providing these benefits does not come without some cost to the instructor, however. It takes considerable time and requires instructors to balance the tradeoffs involved in giving students access to lecture notes. A final consideration is that a commitment to using these technologies is likely to be permanent. After investing the time to develop the materials for the course and seeing the results, few instructors would want to set them aside in future course offerings.

Is it all just bells and whistles? After all, given the choice between watching something a little more like television and watching a professor talk and write on a blackboard, is it surprising that students overwhelmingly prefer the former? Perhaps not. But we were heartened by the fact that students also felt that the technologies we employed helped them learn the material and did not just make attendance in class a little more enjoyable. On the other hand, we did not notice any particular improvement in test scores. We think there are several reasons why this might be true. First, we did not conduct any multivariate analyses to determine whether test scores were stable if we controlled for other factors, nor did we create our tests with experimental design in mind. It is possible, then, that the test scores might have dropped if we had not used the new technologies. We simply do not know. Of course, a second explana- tion is simply that unimproved student performance indicates that the technology really does not help students learn the material any better. A more optimistic version of this point is that new modes of delivery require new or revised methods of assessment. Neither of us changed our exam format extensively when integrating this new technology, and the technology may build skills and impart knowledge in a manner not well tapped by our existing exam structure. A final possible explanation for why test scores did not jump when we introduced the new technology may be that we are still new enough at this that we have not yet learned how to take full advantage of the technology's pedagogical potential.

If we had to guess which students benefited most from our use of this technology, we would conclude that it was those in the middle. On the one hand, the best students can do well regardless of how instructors deliver course material. On the other, struggling students may tend to incorrectly assume that if information is not on the lecture slides then it does not need to be written down or remembered. Students in the middle, however, may find that having the slides gives them a reliable framework for recording, studying, and understanding the material.

At minimum, students emerged from lectures in these courses believing they had a solid overall grasp on the course material. We surmise that the high level of organization in the material may have fostered productive learning outside of class. As instructors, we believe we have made improvements in our teaching of the large lecture class that would have been hard to achieve using traditional methods. It will take more experimentation within the classroom to exploit the payoffs, and avoid the pitfalls, of using instructional technology, but we are encouraged that the experiment is worth pursuing.

\section{Notes}

1. Some students at Virginia Tech, for example, were not entirely happy with new mathematics courses in which they followed computer tutorials in a laboratory instead of attending lectures and sections. Even so, early data on failure rates for the online courses suggest that the instructional technology has increased students' performance (Jeffrey Young 1998a).

2. Such an assessment would entail random assignment of students into two classes taught by the same instructor. One group would be taught by traditional methods, the other by technology-enhanced methods. The course content would be identical, with the exception 
of features only feasible in the technologyenhanced course, as would the assignments and grading criteria. Everything else, including the length of class, quality of teaching assistants, enthusiasm in delivery of the material, and so on, would have to be held constant. Only if these conditions were met could differences in student performance between sections be attributed solely to the instructor's use of technology.

3. Klemm, for example, reported high satisfaction among students who participated in a multimedia graduate neuroscience course that emphasized collaborative problem solving through online instruction, video conferencing, and multidisciplinary approaches. He also reported that, as an instructor, he found the experience "refreshing and motivating" (1998, 370 ). Although it may be difficult to quantify, few would contest that student learning is very likely enhanced in this kind of environment.

4. Through a recently established faculty development program, we received laptop computers and related hardware, software, and training. We also had access to a professional in-house staff familiar with multimedia technology and could request up to 100 hours of student work-study help. We gratefully acknowledge the professional technical assistance we received from Carole Turner, Sue Weier, and Read Gilgen.

5 . We told students that their participation was both voluntary and anonymous. We asked those who took part to submit their responses on answer sheets that contained no identifying information and were not attached in any way to the exam answer sheet. No information was recorded, or even available, about which students submitted answers and which students did not. Administering the survey during the exam period maximized the number of students who could take part. The survey instrument is available from the authors.

6 . These differences are limited to assessments of the usefulness of the web notes. Students in all three section types were equally likely to state that the use of instructional technology in class helped them learn the course material.

7. According to Keuchler, "not providing [web] summaries just to keep class attendance high is a rather poor strategy" $(1999,148)$.

8 . We were surprised by just how common use of this technology had become at our institution. About a third of our students reported that their first exposure to multimedia lectures came in our classes. Just over a fifth said they had taken a course in which multimedia technology was used in less than half the lectures. Fully $44 \%$ indicated they had taken another course in which the instructor used technology for at least half the classes. We attribute this to the university's efforts to encourage faculty to use this technology, the redesign of classrooms to accommodate it, and the presence in our classes of freshmen and sophomores, precisely the groups likely to be taking large introductory courses where such technology is currently most commonly used.

\section{References}

Bollentin, Wendy Richard. 1998. "Can Information Technology Improve Education? Measuring Voices, Attitudes and Perceptions." Educom Review 33(February): 5055.

Campus Computing Project. 1998. The 1998 National Survey of Information Technology in Higher Education < www.campuscomputing. net>. Encino, CA: Campus Computing Project. Accessed: June 16, 2000.

Crawford, Sue E.S. 1998. "Internet Lite: Short Internet Assignments for American Government Courses." PS: Political Science and Politics 31(September): 573-77.

Ehrmann, Stephen C. 1995. "Asking the Right Questions: What Does Research Tell Us About Technology and Higher Learning." Change 27(March/April): 20 27.

—. 1998. "What Outcomes Assessment Misses" < www.tltgroup.org/programs/ outcomes.html>. Presented at the American Association for Higher Education Assessment Conference, Washington, DC. Accessed: June 16, 2000 .

—. 1999. "What Do We Need to Learn about Technology Use in Education?" $<$ http://www.tltgroup.org/resources/ fquestions.html>. Washington, DC: The TLT Group. Manuscript. Accessed: June $16,2000$.

Garson, G. David. 1998. "Evaluating Implementation of Web-Based Teaching in Political Science." PS: Political Science and Politics 31(September): 585-90.

Gizzi, Michael C., and William R. Wilkerson. 1998. "Teaching Effectiveness of the World Wide Web in the Political Science
Classroom: An Invitation" Presented at the Annual Meeting of the American Political Science Association, Boston.

Guernsey, Lisa. 1999. "With Web Skills-and Now Tenure-a Professor Promotes Improved Teaching." The Chronicle of Higher Education, February 26, A24-25.

Janda, Kenneth. 1992."Multimedia in Political Science: Sobering Lessons from a Teaching Experiment." Journal of Educational Multimedia and Hypermedia 1(4):341-54.

Jordan, Donald L., and Peter M. Sanchez. 1994. "Traditional vs. Technology-Aided Instruction: The Effects of Visual Stimulus in the Classroom." PS: Political Science and Politics 27(March): 64-67.

Keuchler, Manfred. 1999. "Using the Web in the Classroom." Social Science Computer Review 17:144-61.

Kiasatpour, Soleiman M. 1999. "The Internet and Film: Teaching Middle East Politics Interactively." PS: Political Science and Politics 32(March): 83-90.

Klemm, W.R. 1998. "New Ways to Teach Neuroscience: Integrating Two Teaching Styles and Two Instructional Technologies." Medical Teacher 20(4): 364-70.

Kuzma, Lynn M. 1998. "The World Wide Web and Active Learning in the International Relations Classroom." PS: Political Science and Politics 31(September): 57884.

Martocchio, Joseph J. 1994. "The Effects of Absence Culture on Individual Absence." Human Relations 47:243-62

McArthur, David J., and Matthew W. Lewis. 1998. Untangling the Web: Applications of the Internet and Other Information Tech- nologies to Higher Learning. Santa Monica: RAND.

McCabe, Donald L., Linda Klebe Trevino, and Kenneth D. Butterfield. 1999. "Academic Integrity in Honor Code and NonHonor Code Environments." The Journal of Higher Education 70:211-34.

Neal, Ed. 1998. "Using Technology in Teaching: We Need to Exercise Healthy Skepticism." The Chronicle of Higher Education, June 19, B4-5.

Privateer, Paul Michael. 1999. "Academic Technology and the Future of Higher Education: Strategic Paths Not Taken." The Journal of Higher Education 70(January/ February): 60-79.

Schwartz, Peter. 1997. "If You Build It, Will They Come to Class?" Human Ecology Fonum 25:9-10.

Wilson, David L. 1996. "Self-Paced Studies: An Experiment at Brown U. Replaces Chemistry Lectures with On-Line Tutorials." The Chronicle of Higher Education, February 26, A19-20.

Young, Jeffrey R. 1998a. "Students Dislike Va. Tech Math Classes in Which Computers Do Much of the Teaching." The Chronicle of Higher Education, February 20, A32-33.

Young, Jeffrey R. 1998b "Skeptical Academics See Perils in Information Technology." The Chronicle of Higher Education, May 8, A29-30.

Young, Jerome. 1998. "Computers and Teaching: Evolution of a Cyberclass." PS: Political Science and Politics 31(September): $568-72$. 